\title{
Ordenamento territorial e conflitos por terra no Amapá - Amazônia - Brasil
}

\author{
Roni Mayer Lomba \\ Universidade Federal do Amapa - Macapá - Amapá - Brasil \\ ORCID: https://orcid.org/0000-0001-6062-6142
}

Alejandro Fabian Schweitzer

Consejo Nacional de Investigaciones Científicas y Técnicas: Rio Gallegos - Santa Cruz - Argentina

ORCID: https://orcid.org/0000-0002-7605-0827

Jadson Luís Rebelo Porto

Universidade Federal do Amapa - Macapá - Amapá - Brasil

ORCID: https://orcid.org/0000-0002-0316-3898

\section{Resumo}

Este artigo analisa os conflitos agrários envolvendo o campesinato tradicional e as grandes atividades capitalistas no Estado do Amapá, Amazônia brasileira. Buscamos desvendar, a partir da geografia agrária e do avanço da fronteira, as características da ocupação, a gênese dos povos locais, as políticas de ordenamento fundiário e como elas tem beneficiado determinados grupos no acesso a terra e exploração dos recursos naturais. Essencialmente, os conflitos encontram-se estabelecidos pela expansão da agropecuária em terras públicas ocupadas por camponeses posseiros, pela construção de barragens para hidrelétricas, afetando populações ribeirinhas, pelo desmatamento de florestas e exploração mineral, atingindo povos indígenas e outros. A pesquisa percorre uma análise crítica via materialismo dialético com a revisão teórica e histórica do lugar, da dinâmica da fronteira, realização de entrevistas qualitativas e construção de dados quali-quantitativos. Conclui-se que a existência de um projeto político local atende aos grandes interesses privados, frente à uma sociedade que reivindica seus direitos ao território enquanto meio de vida.

Palavras chave: Disputas territoriais. Amazônia amapaense. Fronteira. Ordenamento territorial.

\section{Land use and conflicts over land in Amapa - Amazon - Brasil}

\section{Abstract}

This article analyzes the agricultural conflicts involving the traditional peasantry and the great capitalist activities in the State of Amapa, Brazilian Amazon. We seek to unveil, 
through the agricultural geography, and the advance of the frontier, the characteristics of the occupation, the genesis of the local peoples, the policies of land use and how they have benefited certain groups towards the access to land and exploration of natural resources. Essentially, the conflicts are established by the expansion of the agriculture in public lands occupied by peasants that are landholders, by the construction of dams for hydroelectric plants, affecting riverside populations for the deforestation and mineral exploration, harming indigenous peoples and others. The research is developed through a critical analysis via dialectical materialism with a theoretical and historical review of the place, of the dynamics of the frontier, execution of qualitative interviews and construction of qualiquantitative data. It is concluded that the existence of a local political project serves the great private interests, towards a society that claims for their rights to the territorry, which is their livelihood.

Keywords: Land conflicts. Amazon from Amapa. Frontier. Land Use.

\section{Planificación territorial y conflictos de tierras en Amapá - Amazonia - Brasil}

\section{Resumen}

Este artículo analiza los conflictos agrarios que involucran al campesinado tradicional y a las grandes actividades capitalistas en el Estado de Amapá, en la Amazonia brasileña. Buscamos desvelar, desde la geografía agraria y el avance de la frontera, las características de la ocupación, la génesis de los pueblos locales, las políticas de planificación de la tierra, y cómo han beneficiado a ciertos grupos en el acceso a la tierra y la explotación de los recursos naturales. Esencialmente, los conflictos se establecen por la expansión de la agricultura y la ganadería en tierras públicas ocupadas por ocupantes ilegales, por la construcción de presas para hidroeléctricas, que afectan a las poblaciones ribereñas, por la deforestación de los bosques y la explotación de minerales, llegando a los pueblos indígenas y otros. La investigación pasa por un análisis crítico a través del materialismo dialéctico con una revisión teórica e histórica del lugar, la dinámica de la frontera, las entrevistas cualitativas y la construcción de datos cualitativos-cuantitativos. Se concluye que la existencia de un proyecto político local responde a los grandes intereses privados, frente a una sociedad que reclama sus derechos sobre el territorio como medio de vida.

Palabras clave: Disputas territoriales. Amazonia amapaense. Frontera. Planificación territorial.

\section{Introdução}

O Amapá é um estado pertencente à República Federativa do Brasil, localizado na Amazônia brasileira, com divisas fronteiriças a Sul e Sudeste (pelo Rio Amazonas), e Oeste (pelo Rio Jari) com o estado do Pará; Norte e Noroeste com a Guiana Francesa (pelo Rio Oiapoque) e Suriname; e banhado pelo Oceano Atlântico a Nordeste (presentes no Mapa 1).

Como tema e objetivo desta pesquisa analisamos o contexto do ordenamento fundiário e conflitos por terras, ou seja, as disputas paradigmáticas que põem de frente a reprodução dos modos de vida dos povos tracionais que diretamente estão relacionados ao uso sustentável dos recursos naturais e seus direitos legais ao território frente à política de desenvolvimento pautada na exploração privada da terra com degradação da natureza. Tratam-se de disputas socioterritoriais, ou seja, a luta de classes em uma região fronteiriça, de expansão humana e do capital. 
Compreendemos o Amapá como espaço fronteiriço em termos de expansão do capital sobre o território. Nesse sentido, as disputas paradigmáticas se põem em evidência, a cultura e o modo de vida tradicional versus a modernização via capitalização. Percorremos, pela bibliografia referente ao tema e ao lugar, via orientação crítica; pelo materialismo dialético, utilizamos o recurso das entrevistas orais com sujeitos envolvidos junto aos movimentos socioterritoriais, coleta de dados quantitativos e sistematização dos conflitos, e também o uso de imagens e mapas a fim de representar elementos da análise.

Dessa forma dividimos o trabalho da seguinte maneira: primeiro, uma análise sobre a organização do território amapaense; no segundo ponto, a gênese dos conflitos e formação socioterritorial no Estado; e, por último, enfatizamos a expansão dos conflitos pelo agronegócio, pelas hidrelétricas, setor madeireiro e mineração. Analisamos que o avanço dos conflitos na região é parte do projeto nacional de expansão das fronteiras econômicas com vistas em expopriar recursos naturais baratos para exportação.

\section{Amapá: aspectos e contexto da organização do território}

Para exemplificar o contexto da formação histórica do território amapaense recorremos a alguns momentos importantes:

O primeiro momento analisado foi a inserção de atividades extrativistas dominadas por grupos locais que controlavam a circulação de mercadorias (aviamento) e a exploração de recursos florestais (castanha, borracha e outros), entre o final do século XIX e início do XX, integrando a geopolítica liberal britânica de exportação/importação. Ocorre a definição das fronteiras com a Guiana Francesa em 1900, a migração nacional mais representativa, especialmente nordestinos, como mão de obra nos seringais/castanhais, e aqueles que buscam a terra para reprodução de vida e formam o primeiro tecido social não indígena na região.

No segundo momento, o enfraquecimento político/econômico, com a decadência das atividades extrativas, marca a criação do Território Federal do Amapá, em 1943, que junto trazia, como proposta, o desenvolvimento de atividades capitalistas privadas, mas com forte incentivo público, agora sob hegemonia taylorista capitaneada pelos Estados Unidos durante a Guerra Fria. Destacam-se a Indústria e Comércio de Minérios S.A. (ICOMI), Jari Celulose e a Amapá Florestal e Celulose S.A. (AMCEL). Em 1988 é extinto o Território Federal, tornando-se Estado.

No terceiro momento, nos anos 1980, com a agenda ambiental internacional ${ }^{1}$ temos uma reorientação da política local aliada às pressões sociais dos povos tradicionais extrativistas, permitindo a criação de unidades de conservação, homologação de terras indígenas, assentamentos da reforma agrária (grande parte, agroextrativistas) e reconhecimento de alguns territórios quilombola, proporcionando que cerca de $70 \%$ do território amapaense estivesse de certa maneira protegido.

No quarto momento, iniciando o século XXI e mais acentuadamente a partir de 2010, há a retomada da agenda desenvolvimentista, não mais a taylorista do século XX, mas de caráter neoliberal, com menor atuação do Estado e maior precariedade do trabalho, despontando a China como principal mercado

\footnotetext{
Ver Agenda 21 Brasileira (2004).
} 
consumidor de matérias primas do país. Com a demanda internacional aquecida, o Amapá aponta outra vez como zona de expansão da fronteira do capital para produtos primários: alimentos, energia, madeira e minérios.

Contudo, discute-se atualmente a relação entre o terceiro e quarto momento (conservação X exploração) ditando as dinâmicas e as orientações políticas: entre os setores que defendem menos natureza e mais crescimento econômico contra aqueles que apoiam uma economia atrelada à sustentabilidade e manutenção das práticas tradicionais. Em meio a isso, os movimentos socioterritoriais ${ }^{2}$ continuam escrevendo e fazendo parte da história local, sendo fundamentais para a demarcação de um novo conceito de área protegida (as reservas extrativistas de uso sustentável), o reconhecimento e luta pelos direitos dos povos indígenas, quilombolas e, recentemente, os ribeirinhos.

Enquanto na macropolítica decisória ocorre essa disputa paradigmática (reproduzir capital $X$ preservar a natureza), no território o que temos são: camponeses posseiros, no termo jurídico ${ }^{3}$, e povos tradicionais que lutam por permanecerem no território de vida/existência contra o interesse capitalista pela terra e recursos. A terra para o camponês/quilombola, a água para o ribeirinho, a floresta para o extrativista e o indígena, ou a totalidade desses elementos conjugados entre si são indissociáveis a suas vidas, do trabalho, cultura e temporalidade. No sentido inverso, para o agronegócio, a usina hidrelétrica, mineradoras e madeireiras, o território e a natureza são meros recursos transformados em mercadorias para reprodução do capital.

Em termos de movimentos sociais de maior relevância no Amapá, na defesa dos povos tradicionais, destacamos: a $\mathrm{CPT}^{4}$; o $\mathrm{MAB}^{5}$; o $\mathrm{CNS}^{6}$; em caráter mais recente a $\mathrm{FNL}^{7}$ e o $\mathrm{FACADE}^{8}$. Em termos sindicais, existem diversas associações vinculadas à FETAGRAP ${ }^{9} \mathrm{e}$, em relação aos povos indígenas, a ONG IEPÉ ${ }^{10}$.

\footnotetext{
2 Fernandes (2005, p. 26) define a categoria socioterritorial por: “... pensar os espaços e os territórios como forma de compreender melhor as conflitualidades".

3 Aquele que não possui a propriedade jurídica da mesma, mas são reconhecidos perante a lei - ver Trecanni (2009).

4 Comissão Pastoral da Terra. Criada em 1975, é ligada à Igreja Católica e atua diretamente com camponeses em situação de vulnerabilidade e de conflito; tem denunciado sistematicamente as ações de empresários e do Estado em retirar populações que originalmente ocupam as terras, mapeando, registrando e intermediando junto à justiça. No Amapá, iniciaram suas atividades no início da década de 1980 (SILVA a., 2018). Vide, também, https://www.cptnacional.org.br/.

5 Movimento de Atingidos por Barragens. Criado enquanto movimento nacional em 1991, atua junto aos camponeses ribeirinhos afetados pela construção de barragens, que diretamente está relacionado tanto à perda da terra de trabalho/moradia quanto pela dificuldade de reprodução das formas de sobrevivência (afetamento da pesca artesanal e agricultura), além dos prejuízos ambientais. No Amapá, desde 2016. Fonte: www.mabnacional.org.br.

${ }^{6}$ Conselho Nacional de Seringueiros. Criada nacionalmente em 1985 pelos seringueiros, a partir do Sindicato dos Trabalhadores Rurais (http://memorialchicomendes.org). Foi o maior movimento social de luta pela terra na Amazônia nos anos 1970/1980, tendo sido relevante na denúncia dos impactos ambientais provocados pelos projetos econômicos na Amazônia, denunciando a expulsão de camponeses extrativistas e lutando pela criação de reservas extrativistas.

7 Frente Nacional de Lutas, Campo e Cidade: movimento social que reivindica reforma agrária, criado por José Rainha Júnior a partir da dissidência junto ao Movimentos dos Trabalhadores Sem Terra MST.

${ }^{8}$ Fórum de Acompanhamento de Conflitos Agrários e Desenvolvimento. Composto por pesquisadores de universidades, estudantes, funcionários públicos, ONGs, sindicatos e sociedade civil; reúnem-se periodicamente para fins de mobilização, organização de eventos, publicações,
} 
Possuindo uma extensão territorial de $142.827,89 \mathrm{~km}^{2}, 16$ municípios e uma população estimada de 845.494 habitantes (IBGE, 2019), sendo que, em 2010, já apresentava índices de 89,8\% urbana e 10,2\% rural (IBGE, 2010); o Amapá possui uma economia embasada no extrativismo vegetal e na mineração, sendo a agricultura caracterizada pela produção de excedentes com trabalho familiar, enquanto a pecuária, pela criação extensiva de bubalinos e de gado vacum. Sua produção agrícola é insuficiente para atender a demanda local, o que acarreta na importação de alimentos. Outro fator que o caracteriza é a dependência das transferências de recursos por parte do Governo Federal (destaque ao Fundo de Participação dos Estados), como principal fonte de receita (LOMBA; SILVA, 2014).

Em termos práticos, o Mapa 1 apresenta, de forma geral, os principais conflitos a serem discutidos nesse trabalho.

Mapa 1 - Amapá: áreas sob jurisdição do Estado e conflitos

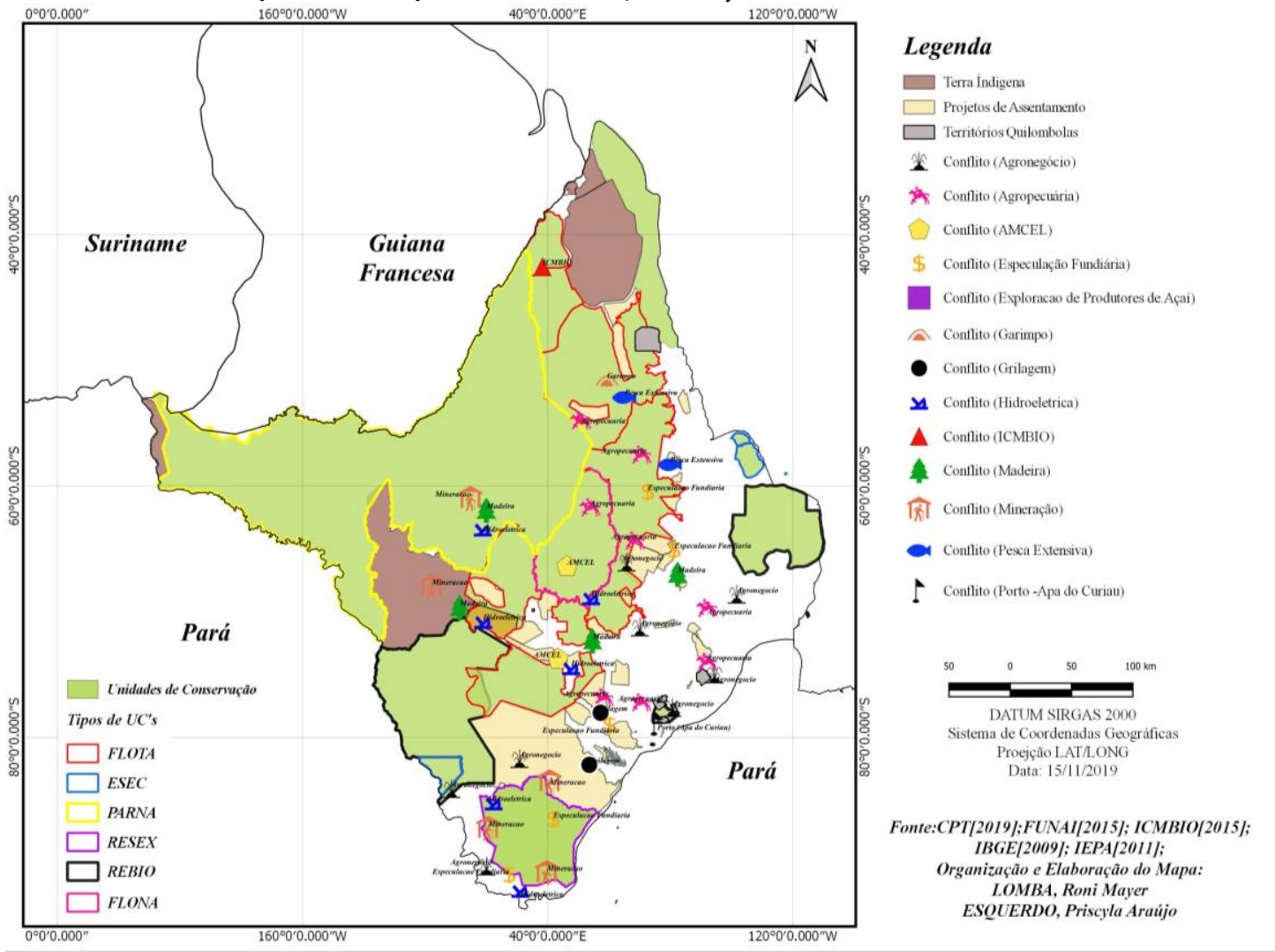

Fonte: CPT(2019); FUNAI (2015); ICMBIO (2015); IBGE (2009); IEPA (2011). Organização e Elaboração do Mapa: Roni Mayer Lomba; Priscyla Araújo Esquerdo.

Construída a partir dos dados fornecidos pela CPT, via publicação anual do Caderno de Conflitos no Campo, a representação aponta a localização dos conflitos

denúncias de conflitos a órgãos competentes, criação de mecanismos de divulgação (site, programa de rádio), entre outros. Criado em 2012 após a realização do I Simpósio Amazônico Sobre Reforma Agrária Meio Ambiente e Desenvolvimento na Universidade Estadual do Amapá (UEAP), em Macapá. Vide http://facadeamapa.blogspot.com/.

9 Federação dos Trabalhadores da Agricultura do Amapá. Instância sindical dos trabalhadores da agricultura, vinculada à Confederação Nacional dos Trabalhadores na Agricultura - CONTAG.

10 Instituto de Pesquisa e Formação Indígena, foi criado em 2002 e atua junto aos indígenas do Amapá e Norte do Pará. 
que são relacionados às atividades empresariais capitalistas (clandestinas ou não). Tanto elas ocorrem em áreas públicas, ainda não oficialmente destinadas (em branco no mapa), quanto nas áreas de preservação, promovendo instabilidades. É fato que tais situações não ocorrem sem a participação dos agentes públicos de controle, fiscalização e até judicial, que em vários momentos foram denunciados ou criminalizados por ações de caráter corruptivo.

As áreas em branco representam aquelas de caráter privado e, principalmente, terras públicas ainda não destinadas oficialmente ou à espera de ordenamento. Em grande parte são ocupadas por populações tradicionais, como camponeses posseiros, ribeirinhos e quilombolas. Trata-se de cerca de $12 \%$ do território estadual que devem ser subtraídas do ordenamento pelo ente federal passando para o Estado ${ }^{11}$. Por lei, toda terra rural pública, segundo o Estatuto da Terra de 1964, deve ser destinada para fins de reforma agrária, regularização de posses e territórios de povos tradicionais, o que vai na contramão das práticas locais que reinvindicam terras para expansão do agronegócio.

A importância de discussão da fronteira, vista a partir do território, necessita ser melhor interpretada dentro desse espaço amazônico. Consideramos aquela relacionada à alteridade que Martins (2009) analisou em tempos anteriores, a do encontro e da barbárie, do moderno e do tradicional, que compõem o par dialético.

O território amapaense, envolvido em variados tipos de conflitos, apresenta um crescimento populacional (em tempos de crise econômica nacional) superior a 26\%, entre 2010 (data do último censo populacional) a 2019 (segundo as projeções do IBGE). Esse fator pode ser analisado porque a expansão da fronteira eleva a migração de força de trabalho, que busca melhores condições de vida.

Nessa conjuntura está envolvida também a expansão da infraestrutura, como o Porto de Santana, rodovias para integração fronteiriça, linhas de transmissão de energia, a inserção do Amapá no planejamento estratégico da antiga IIRSA (Iniciativa para a Integração da Infraestrutura Regional Sul-Americana), atual COSIPLAN (Conselho Sulamericano de Infraestrutura e Planejamento da UNASUL) ${ }^{12}$, estando em dois eixos de integração: Eixo Escudo das Guianas e Eixo Amazônico.

Dentre as inúmeras propostas existentes como promotores de desenvolvimento resgatamos algumas: a implantão e pavimentação das rodovia BR156 que interliga o Amapá Norte (com fronteira com a Guiana Francesa) ao Sul (fronteira com o Pará); a ampliação e melhoramentos do Porto de Santana para exportação de minérios; criação do porto para escoamento da soja produzida no estado do Mato Grosso (maior produtor nacional) a partir do Rio Tapajós, atravessando o Amazonas, via Amapá, para acessar o Oceano Atlântico.

Deveras, alguns indicadores sobre investimentos recentes na região têm sido constatados. Dados coletados junto ao Banco Nacional de Desenvolvimento Econômico e Social do Brasil (BNDES, 2019), apontaram desembolso para

11 Em 2009, o ex-presidente Lula assinou um decreto de repasse de terras que não foi regulamentado. Em 2016 a então presidenta Dilma assina o Decreto 8.713, acerca da transferência, mas, para isso impõe determinadas restrições e prazos. Entrentanto, para facilitar mais os interesses do agronegócio, extinguindo entre outros a necessidade de georeferenciamento, o Governo Bolsonaro, em 2019, assinou o Decreto 901, facilitando e desburocratizando as regularizações fundiárias.

12 Para maiores detalhes ver Rückert e Carneiro (2018) e Fernandes e Diniz Filho (2017). 
financiamento de grandes empresas privadas capitalistas entre 2007 a 2019, sendo elas: Empresa de Energia Cachoeira Caldeirão: $\mathrm{R} \$$ 491.547.000,00; Ferreira Gomes Energia: R\$ 592.307.000,00; CIAMPORT (portos/navegação marítima): R\$ 48.946.804,00; ZAMIN Mineração e Logística: R\$ 498.889.045,00 (\$118.783.106,00 dólares americanos). Percebe-se que os setores que mobilizaram a captação de maiores fatias de recursos com financiamentos públicos são: usinas hidrelétricas, com $\mathrm{R}$ 1.083.854,00; a empresa de logística CIAMPORT, que se dispõe para a construção do porto e compra de navios/rebocadores para grãos, um projeto bastante ambicioso na região; e a empresa de mineração e logística Zamin, de capital indiano.

Merece destaque a empresa Zamin, que representava cerca de $32 \%$ do PIB do Estado, mas desde 2013 abandonou seu projeto de exploração e transporte após acidente que afetou o antigo porto de escoamento, deixando uma dívida para o Estado e aos trabalhadores, decorrente ao não pagamento de salários e encargos.

Segundo dados do Banco da Amazônia (2019), entre 2009 a 2019 houve desembolso de $\mathrm{R} \$ 1$ 1.222.521.798,89; desse montante, $\mathrm{R} \$ 844.800 .858,19$, cerca de $69,10 \%$, foram para atendimento de clientes/atividades de grande porte, ou seja, as atividades econômicas mais ricas foram aquelas que receberam mais recursos públicos em termos de financiamento. Esses dados reforçam nossa análise, a do Amapá como área de expansão econômica do país baseada em grandes projetos econômicos capitalistas.

Como resultado, os grandes projetos econômicos promovem sistemáticos conflitos socioterritoriais contra os povos tradicionais na disputa pelo território. Nos capítulos a seguir, construídos a partir de informações públicas ou junto aos movimentos sociais, como a colaboração da Comissão Pastoral da Terra (CPT) e do Movimento dos Atingidos por Barragens (MAB), apresentamos as principais problemáticas que analisamos nos úlitmos anos: o avanço da fronteira e os conflitos socioterritoriais.

\section{Conflitos e movimentos socioterritoriais no Amapá}

O histórico de conflitos fundiários no Amapá, segundo a CPT, foram gerados pela AMCEL, após aquisição, via leilão, de terras públicas pelo INCRA (Instituto Nacional de Colonização e Reforma Agrária), na década de 1970, promovendo expulsão de posseiros ali presentes. Também se reporta às relações conflituosas entre camponeses e fazendeiros criadores de búfalos, especialmente sobre os prejuízos que esses animais traziam aos posseiros, ao destruírem plantações. Foram realizados trabalhos de organização dos ribeirinhos pelo reconhecimento das terras em Afuá e adjacências, no estado do Pará, contra o desmatamento e expulsão promovida por madeireiros. Porém, a relativa escassez de confrontos diretos (como mortes e outras formas de violência explícita) entre camponeses e fazendeiros rendeu uma anedota até recentemente comum na região: a de que não existe conflitos diretos ou se existem, trata-se por "brigas de vizinhos", coisas de menor relevância (LOMBA; SILVA, 2014).

Alguns casos pontuais apontavam para a evolução de conflitos na década de 1990, como o assassinato de 4 membros de uma família de agricultores no município de Amapá (família Magave), em 1994, por pistoleiros contratados por 
uma empresa que disputava os limites da terra. Em 1998 ficou conhecido também o assassinato de Maria de Nazaré Souza Mineiro, no município de Laranjal do Jari, uma liderança camponesa que reinvidicava o assentamento de um grupo de trabalhadores rurais em terras também reinvidicadas por latifundiários e empresas. Soma-se a isso, a devolução de 140.000 ha pela $A M C E L^{13}$, em 2004, de terras comprovadamente griladas (SANTIAGO, 2013). Segundo Gallazi (2016, p. 194),

a Pastoral da Terra vinha denunciando o aumento de conflitos por terra no Estado desde 1995, com forte recrudescimento a partir de 2004. De lá para cá os conflitos por terra e devastação ambiental só vieram aumentando em proporção geométrica e não há sinal de que possam diminuir. Pelo contrário: a cegueira, a incompetência e/ou a conivência dos órgãos públicos, em nome de um pretenso desenvolvimento do Estado, continuam favorecendo esta situação de grave ilegalidade.

Entre os anos 1970 a 2000, os problemas com relação à terra foram concentrados por duas grandes empresas: o Projeto Jari Celulose e a Amapá Celulose (AMCEL). A primeira, localizada na divisa com o Pará e a segunda na região central do Estado. Incentivadas e financiadas durante a ditadura estabeleceram latifúndios, superando os 200.000 ha, no caso da AMCEL, e os 1.500.000 ha da Jari Celulose. No caso da Jari, a compra das terras matriculadas em nome de José Júlio, no cartório de Almerim (Pará), foram vendidas a terceiros até serem adquiridas pela empresa, o que gerou o conflito que resultou na formação do movimento de defesa dos extrativistas (CNS) para criação de reservas de uso sustentável. No caso da AMCEL, esta conseguiu suas terras por meio de arremate de um lote no leilão do INCRA em 1978 (destinado ao plantio de pinus), além de outras empresas, como a ICOMI, sendo posteriormente as terras recompradas pela AMCEL, conformando o latifúndio. Além disso, a empresa possui diversos indícios de irregularidades cartoriais, expandindo (com indícios de grilagens) a expansão de suas áreas, como atestado pelas denúncias da CPT (SANTIAGO, 2013).

No decorrer do início do século XXI observamos uma nova etapa da frente pioneira para expansão de atividades capitalistas na disputa pelo território. Os principais recursos naturais cobiçados pelo mercado são as terras no micro-bioma de cerrado presente na Amazônia amapaense e sua incorporação à agropecuária; os recursos hídricos para a construção de barragens para hidrelétricas; e exploração mineral.

Em termos de dados de conflitos da CPT entre 2009 a 2018, apontaram o seguinte:

\footnotetext{
${ }^{13}$ Iniciada em 1976 como subsidiária do Grupo CAEMI, iniciando os plantios de Pinus em 1977. Em 1996, a Champion Papel e Celulose adquiriu os direitos acionários da AMCEL e em 2000 a International Paper do Brasil Ltda., assumiu o grupo Champion. Atualmente o controle acionários da AMCEL pertence aos Grupos Japoneses, Nippon Paper Industries e NYK - Nippon Yusen Kabushiki Kaisha. Fonte: http://www.amcel.com.br/\#about/.
} 
Tabela 1 - Amapá: número de conflitos

\begin{tabular}{|l|c|c|c|c|c|}
\hline Ano & $\begin{array}{c}\text { Conflitos } \\
\text { (número) }\end{array}$ & $\begin{array}{c}\text { Famílias } \\
\text { (número) }\end{array}$ & Área (ha) & $\begin{array}{c}\text { Trabalho } \\
\text { Escravo } \\
\text { (libertos) }\end{array}$ & $\begin{array}{c}\text { Conflitos } \\
\text { pela } \\
\text { água } \\
\text { (famílias) }\end{array}$ \\
\hline 2009 & 56 & 1.771 & 200.323 & & 20 \\
\hline 2010 & 49 & 1.496 & 189.785 & & 20 \\
\hline 2011 & 50 & 2.185 & 196.954 & & 150 \\
\hline 2012 & 55 & 2.186 & 225.264 & 3 & 150 \\
\hline 2013 & 79 & 1.931 & 406.770 & & 339 \\
\hline 2014 & 74 & 1.888 & 466.370 & & 359 \\
\hline 2015 & 64 & 1.908 & 410.065 & & 0 \\
\hline 2016 & 47 & 1.919 & 220.445 & & 220 \\
\hline 2017 & 45 & 1.156 & 221.208 & 11 & 268 \\
\hline 2018 & 46 & 1.285 & 237.975 & & 520 \\
\hline
\end{tabular}

Na análise da tabela, a relação de expansão de conflitos-famílias-áreas foi diretamente relacionada às grandes atividades capitalistas (agronegócio, madeira, energia, minério) em relação aos grupos tradionais. A redução de conflitos ocorre por razão de solução de alguns destes, por decisões judiciais, algumas vezes favoráveis ao camponês e, majoritariamente, ao capitalista individual ou grandes empresas, com destaque recente a AMCEL, segundo informações diretas junto à CPT.

Sobre isso, considera-se os seguintes fatos: a obtenção da renda fundiária, no caso, pela apropriação privada da terra pública é fator relevante para o capitalismo agrário (MARX, 1988); há demandas por matérias-primas baratas; o Amapá se põe como espaço estratégico para isso, ou seja, a capitalização da natureza (MOORE, 2017); e o território está em constante fase de avanço da frente pioneira (MARTINS, 2009).

\section{Regularização fundiária e agricultura capitalista}

No Estado, a situação fundiária ainda se apresenta como precária e caótica. No Brasil, a aprovação da Lei de Terras, em 1850 (Lei $n^{\circ}$ 601) criou o primeiro mecanismo legal de transposição da terra pública para proprietários privados (SMITH, 1990). Na primeira Constituição da República Federativa, de 1891, o Estado transferiu a responsabilidade de regularização fundiária para os entes federativos, sendo estes incumbidos de criar os mecanismos para tal, fator que permitiu a expansão da grilagem, o comércio de terras no país, beneficiando elites regionais (FELICIANO, 2009). Com a criação do Território Federal do Amapá, em 1943, essas terras voltam à incumbência do gestor nacional, e, se tratando de terras que pouco interessavam à agropecuária capitalista na época, não estavam registradas para privados. A terra, portanto, permanecendo pública, permitiu posteriormente a criação de extensões consideráveis de áreas protegidas, como parques, terras indígenas, assentamentos agroextativistas, entre outros. 
A transformação de Território Federal em Estado, em 1988, não transferiu automaticamente as terras para sua gestão. Pelas novas regras constitucionais tornava-se necessário passar pela demarcação e destinação das respectivas matrículas, que continuam sob a tutela federal (parques, terras indígenas, assentamentos federais, quilombos e outros). Para agilizar e facilitar o processo de regularização fundiária na Amazônia, o Governo Federal cria a Lei no 11.952/2009, institucionalizando o Programa Amazônia Terra Legal, vinculado à SERFAL/MDA ${ }^{14}$, com a incumbência de reconhecer e regularizar imóveis ocupados por posseiros, especialmente aqueles que possuíssem entre 1 a 4 módulos fiscais ${ }^{15}$ (em casos específicos, até 15 módulos).

Recentemente, as alterações da Lei $n^{\circ}$ 13.465/17 ampliou o limite de terras para regularização de 1500 para 2500 ha $^{16}$, possibilitando que assentados vendam o lote antes de completarem 10 anos na terra, o que fragiliza as punições àquelas propriedades que não cumprirem a função social e estimula os latifúndios.

\begin{abstract}
O aumento da quantidade de terras possíveis de serem regularizadas pode, especialmente na Amazônia Legal (e no Amapá), onde se tem uma grande quantidade de terras públicas, que serão objeto da regularização fundiária prevista, aumentar, ainda mais, os conflitos e a concentração das terras na região. Essa medida, (...) facilita a regularização fundiária de terras públicas e devolutas, possibilitando, inclusive, a legalização da grilagem, uma vez que amplia para 2.500 hectares o limite da área de terra devoluta passível de ser regularizada na Amazônia pelo Programa Terra Legal (...). (SILVA b., 2018, p. 18-19).
\end{abstract}

A situação jurídica instável e a falta de políticas efetivas para enfrentar o problema colocam de frente as classes que determinam a reprodução dos conflitos. Por um lado, o Estado tem promovido (mesmo sem condições jurídicas efetivas) a divulgação de oportunidades para empresários de outras regiões ali estabelecerem negócios agropecuários, a estruturação de um contexto de grilagem que envolve altos funcionários públicos em corrupção, cartórios de imóveis, empresários e políticos que foram denunciados pela CPT junto aos órgãos de controle e fiscalização (especialmente o Ministério Público Federal - MPF). Por outro lado, camponeses com histórico de ocupação na região são expulsos de seus territórios que, por lei, a eles deveriam ser garantidos (GALLAZI, 2016).

\footnotetext{
${ }^{14}$ Secretaria de Regularização Fundiária da Amazônia Legal vinculada ao extinto Ministério do Desenvolvimento Agrário.

${ }^{15}$ Trata-se do parâmetro utilizado pelo Instituto Nacional de Colonização e Reforma Agrária (INCRA), pela Lei $n^{\circ} 6.746 / 79$, que regula os direitos e obrigações relativos a imóveis rurais, para os fins de execução da reforma agrária e promoção da política agrícola nacional. Possui variação a cada município que leva em consideração o tipo de exploração predominante, a renda, outras explorações e o conceito de propriedade familiar. Considera-se por área mínima para exploração econômica viável e, em conjunto, a Lei ${ }^{\circ} 8.629 / 1993$ define os critérios de minifúndio, pequena, média e grande propriedade. No Amapá, o módulo fiscal predominante é o de 50 hectares, salvo alguns municípios com 70 hectares/módulo.

${ }^{16}$ Considerando, no caso, alguns municípios da Amazônia que possuem módulo fiscal de 100 ha. No Amapá a extensão de 25 módulos chegaria, no máximo, a 1750 ha.
} 


\section{Em entrevista a campo com representantes da CPT:}

eles (grileiros) andaram cercando áreas inteiras, alguns pra plantar, outros para fins especulativos; andaram criando problema com pequenas comunidades locais; hoje, você anda daqui até Calçoene, você não tem um metro que não esteja em conflito, por causa dessas pessoas aí, que vieram e andaram se servindo de instrumentos que a própria união, que o próprio poder público colocou na serviço deles, como o SIGEF e o CAR. (...) O estado tem uma política que reza que o agrobusiness, o agronegócio é o grande, é aquele que vai salvar o Amapá da fome, que vai tirar o Amapá do atraso, tudo isso vai salvar o Amapá, mineração, madeireira, eucalipto, tudo isso vai, ele (Governador do Estado, Waldez Góes) chama de setor produtivo, é aquele que vai salvar o Amapá, e aí, o que o estado faz? O próprio Waldez foi lá no Mato Grosso visitar as empresas do agronegócio de lá, voltando com a promessa de ajudar essas pessoas a se instalar, que só por falar isso ele ja merecia ser preso, porque você não pode dar a terra a quem não é morador de fato dessa terra, a quem não tem as condições de regularizar essas terras, porque a lei diz que só pode ter acesso quem precisa daquela terra para poder sobreviver e, no entanto, o Waldez, ele faz questão de dizer que esse pessoal receberá facilitação para poder se instalar e ser o setor produtivo, o alavancador do progresso aqui no estado do Amapá, o que não pode, legalmente é inviável isso, se você faz isso você se torna como dizer, você vai transgredir a lei, que você vai destinar terra àquele que não precisa da terra para poder viver, no entanto para o agronegócio, nas palestras, nos encontros que acontece por ali ele mesmo diz, nós queremos $400 \mathrm{mil}$ hectares, mas como pode dizer isso? Eu quero 400 mil hectares, mas como? Se tu não mora lá no lugar, se tu mora lá a mais de $5 \mathrm{mil} \mathrm{km} \mathrm{de}$ distância, como você quer 400.000 ha de terra se você não é um morador do lugar, não reside, não é posseiro de fato daquele lugar? Que tipo de processo adminstrativo vai ter para ti legalizar?

A preocupação e denúncia relatadas na entrevista se materializam quando analisamos no mapa as áreas em situação de regularização de posse via Terra Legal no estado, que toma grande parte da área que reivindica o repasse legal além de sobreposição de fundiária sobre terras de preservação e assentamentos do INCRA. 
Mapa 2 - Amapá: Registros de áreas para regularização

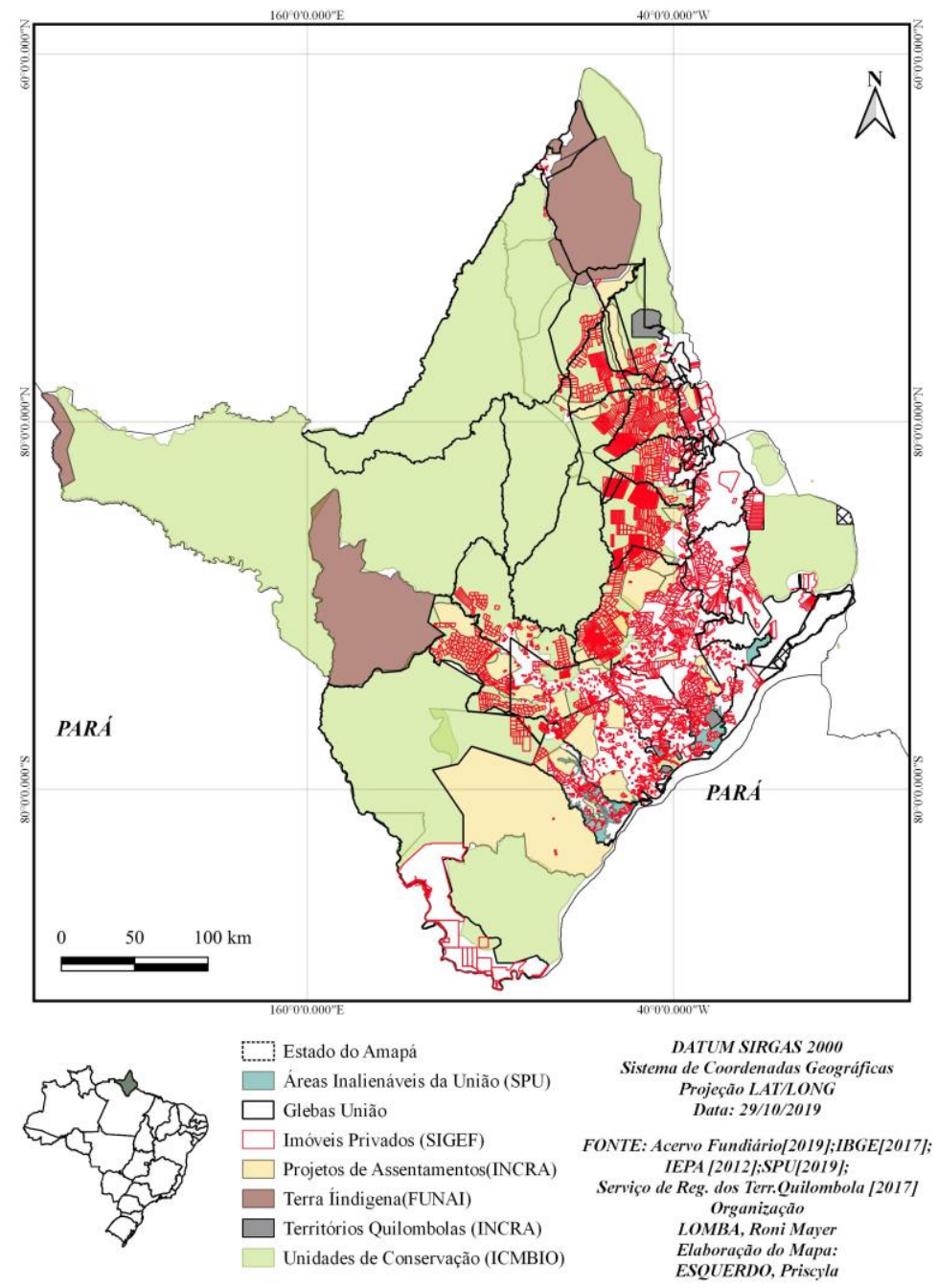

Fonte: Acervo Fundiário (2019); IBGE (2017); IEPA (2012); SPU (2019); Serviço de Reg. dos Terr. Quilombola (2017). Organização: Roni Mayer Lomba. Elaboração do mapa: Priscyla Esquerdo.

Analisando a entrevista e o Mapa 2, compreende-se o complexo processo que envolve a regularização fundiária do Programa Terra Legal. O discurso político de cessão de terras para o agronegócio, aliado às facilidades para regularização de terra pública, tem sido destacado pelo complexo processo de grilagem via georeferenciamento para regularização fundiária, realizado na plataforma Sistema de Gestão Fundiária (SIGEF), no caso, a regularização de posses. Para isso realiza-se uma imagem georreferenciada realizada por técnicos cadastrados pelo INCRA/TERRA LEGAL dentro da plataforma digital e assim iniciar o trâmite. Em casos de posseiros pobres e com área inferior a 2 módulos fiscais, o Estado deve garantir o georeferenciamento de forma gratuita. Porém, o que se observa na imagem são diversas formas de sobreposição com georeferenciamento em áreas de preservação, assentamentos, entre outros. Ao que se indica no mapa, a supervisão tem se apresentado frágil e permissível de irregularidades, apesar das entrevistas junto aos técnicos do INCRA apontarem o contrário, pois, segundo entrevistado, 
"uma vez que a empresa plota uma área para regularização ela não pode retirar mais, assim, se ela cometeu crime, terá que responder por isso".

As denúncias realizadas, especialmente pela CPT junto ao MPF, é que empresários e políticos com poder econômico têm iniciado esse tipo de processo no SIGEF, pagando elevadas somas de recursos para realizar o georeferenciamento, subornando técnicos e funcionários públicos. Normalmente compram uma pequena posse, expandem suas áreas via matrícula emitida pelo cartório (oficialmente irregular) tomando como base, por exemplo, um simples recibo de compra e venda de terra (declaratório), registram a área no Cadastro Ambiental Rural $\left(\mathrm{CAR}^{17}\right)$, requerem (e conseguem) autorização junto ao órgão estadual responsável pela emissão de licenças ambientais para fins de exploração econômica, no caso, se utilizam do Instituto do Meio Ambiente e de Ordenamento Territorial do Estado do Amapá (IMAP), e iniciam suas atividades. Esse conjunto de formas ilegais conforma a base para fomentar grilagem da terra pública.

O IMAP emite uma licença ambiental com base em documentos jurídicos frágeis e, além disso, não possui competência para tanto, tendo em vista que a maior parte das terras continuam federais (ou seja, a licença só poderia ser emitida pelo órgão ambiental federal). Além do IMAP, a Secretaria de Meio Ambiente do Município de Macapá também vem emitindo licenças irregulares para plantio de grãos. Munida desses documentos (juridicamente frágeis e ilegais), a parte interessada acessa a terra, contrata equipes privadas de seguranças e passa a intimidar quem vive sobre a mesma. Queimam plantações, casas, retiram a vegetação nativa, revolvem a terra e iniciam o plantio, às vezes até amparados por liminares judiciais. Mesmo com todas as evidências apresentadas, tem sido comum a justiça dar razão e ganho de causa ao empresário, alegando em laudos que os posseiros eram os ocupantes recentes (por terem reconstruído suas casas recentemente após terem sido destruídas).

Por essas e outras, o clima de insegurança se estabelece. Há diversas denúncias, uma quantidade expressiva de trabalhadores dos órgãos públicos investigados ou até mesmo punidos. Os camponeses sem recursos são obrigados a esperar o Estado realizar seu georeferenciamento, e, pasmem, sua área ocupada há décadas, em vários casos, já se encontram cadastradas no sistema do INCRA e o mesmo passa, então, a sofrer todo tipo de pressão e ser expulso da terra. Eis o exemplo moderno de conflito fundiário no Amapá.

\footnotetext{
${ }^{17}$ Criado pela Lei $n^{\circ}$ 12.651/2012, no âmbito do Sistema Nacional de Informação sobre Meio Ambiente - SINIMA, e regulamentado pela Instrução Normativa MMA n² 2, de 5 de maio de 2014, o Cadastro Ambiental Rural - CAR é um registro público eletrônico de âmbito nacional, obrigatório para todos os imóveis rurais, com a finalidade de integrar as informações ambientais das propriedades e posses rurais referentes às Áreas de Preservação Permanente - APP, de uso restrito, de Reserva Legal, de remanescentes de florestas e demais formas de vegetação nativa, e das áreas consolidadas, compondo base de dados para controle, monitoramento, planejamento ambiental e econômico e combate ao desmatamento. A inscrição no CAR é o primeiro passo para obtenção da regularidade ambiental do imóvel, e contempla: dados do proprietário, possuidor rural ou responsável direto pelo imóvel rural; dados sobre os documentos de comprovação de propriedade e ou posse; e informações georreferenciadas do perímetro do imóvel, das áreas de interesse social e das áreas de utilidade pública, com a informação da localização dos remanescentes de vegetação nativa, das Áreas de Preservação Permanente, das áreas de Uso Restrito, das áreas consolidadas e das Reservas Legais. Fonte: www.car.gov.br/.
} 
Não bastassem todas irregularidades apresentadas, a assinatura do decreto 901 em 2019 da transferência de terras da União para o Estado tende a facilitar mais ainda os interesses privados uma vez que extingue as necessidades de estudos de georeferenciamento e dificultando ainda mais a fiscalização. Utilizando o discurso de se tratar uma lei que beneficia camponeses pobres incapazes de pagar por isso e ao Estado que afirma nao ter recursos para tal, a retirada desses mecanismo facilita as práticas ilegais uma vez que os processos obedecerão o mecanismo declaratório, todo loteamento irregular apresentado nos mapas poderão ser efetivados sem grandes problemas.

As imagens a seguir, cedidas pela CPT, evidenciam o momento posterior à expulsão do camponês/posseiro por grileiros vinculados ao agronegócio, com destruição de casas e plantações.

Figura 1 - Amapá: Conflitos e expulsão de camponeses na rodovia AP-70
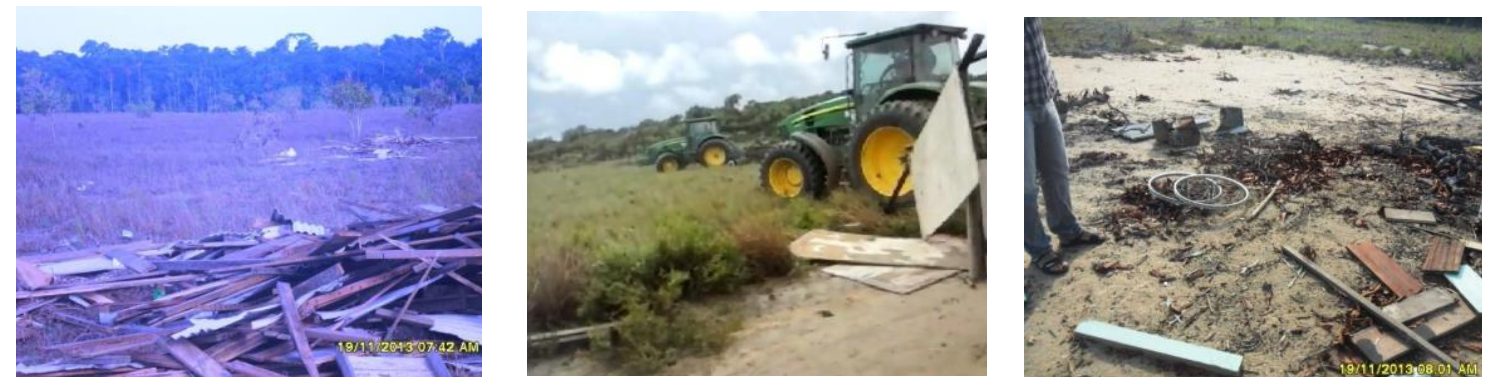

Fonte: Roni Mayer Lomba.

O Amapá até 2016 não estava interligado ao sistema nacional de energia, sendo o consumo doméstico suprido por usinas termelétricas movidas a óleo diesel e uma hidrelétrica. A primeira construída foi a Usina Coaracy Nunes, em 1976, no rio Araguari, que na época visou abastecer a demanda gerada pela exploração de manganês pela ICOMI em Serra do Navio.

A interligação ao sistema nacional e a construção de novas hidrelétricas em tese seria suficiente para abastecimento local, ao mesmo tempo que haveria excedentes para serem comercializados no resto do país. Foram construídas assim três novas: Usina Hidrelétrica Ferreira Gomes Energia, com capacidade de $252 \mathrm{MW}$; Usina Hidrelétrica Cachoeira Caldeirão, com 219 MW (ambas localizadas no rio Araguari entre os municípios de Porto Grande e Ferreira Gomes); e a Usina Hidrelétrica de Santo Antônio, com 373 MW, no rio Jari, município de Laranjal do Jari e na divisa com o Pará. Com exceção da usina Coaracy Nunes, que é gerida pela Eletronorte e pode gerar até $78 \mathrm{MW}$, as demais são empreendimentos privados. Juntas, elas têm capacidade de geração de $922 \mathrm{MW}$, suficientes para demanda de 2.500.000 ${ }^{18}$ habitantes, superando em 3 vezes a população do estado.

O fato de que diversas comunidades rurais ${ }^{19}$ no Amapá ainda não possuem acesso à eletricidade, contrasta com a geração de eletricidade bastante superior à

\footnotetext{
${ }^{18}$ Estimativa realizada a partir das informações coletadas no sítio eletrônico da Usina Ferreira Gomes Energia, no qual refere-se a produção de seus $252 \mathrm{MW}$ suficientes ao abastecimento de 700.000 moradores. Fonte: http://ferreiragomesenergia.com.br/.

${ }^{19} \mathrm{Em}$ diversos momentos de pesquisas a campo e atividades técnicas realizadas na rodovia BR156, em direção a Laranjal do Jari, no distrito do Maracá, pertencente ao município de Mazagão,
} 
demanda estadual, que demonstra uma contradição desse processo, ou seja, gerase excedentes transferidos para outras regiões do país, ao passo que a população local não é devidamente assistida.

De acordo com Guimarães e Batista (2018), também representantes do Movimento de Atingidos por Barragens (MAB), os problemas sociais enfrentados pelos moradores foram assim elencados: nas proximidades da Usina Coaracy Nunes, as pessoas atingidas por sua construção foram assentadas na Área do Proteção Permanente (APP), considerando que no momento da construção desta não havia obrigação, por lei, de reassentar populações atingidas. Nesse caso, estar dentro da APP dificulta o acesso direto aos recursos de reprodução social (caça e pesca artesanal), impedimento do acesso ao lago, problemas de acesso, uma vez que, para entrar em suas áreas e casas é necessário passarem pela guarita da empresa, com devida autorização, derrubada da casa de moradia por funcionários da empresa em momentos de suas ausências.

Em 2008 começaram as audiências públicas nos municípios de Ferreira Gomes, Porto Grande, Macapá e Cutias para fins de apresentar e aprovar, junto à sociedade a ser impactada, a construção dos novos projetos hidrelétricos. Essas audiências, uma exigência para concessão da licença para início das obras, realizadas pela empresa interessada, têm se caracterizado num evento cuja participação social e intervenção é quase nula. $O$ início de uma obra de grande porte, como as hidrelétricas, tem impacto social perverso, considerando as municipalidades pequenas no entorno, das quais se destacam: crescimento urbano, elevação dos preços das mercadorias, do preço da terra urbana, problemas ambientais por escassez de infraestrutura, prostituição, insegurança etc.

Além disso, o impacto ambiental interfere diretamente na vida de quem depende dos recursos hídricos para sobreviver. Estes têm sido denunciados pelo MAB (que foi constituído após a construção das novas hidrelétricas); concentram-se no desmatamento para construção das barragens, mortalidade de peixes pela alta oxigenação das águas, falta de execução dos projetos de minimização de impactos acordados entre as empresas e as comunidades, riscos sociais proporcionados, como o caso da inundação na cidade de Ferreira Gomes, em 2015, provocados pela abertura das compotas de forma inadequada (GUIMARÃES; BATISTA, 2018). Somase a isso as consequências ambientais provocadas pela redução da vazão do rio Araguari, assoreamento da foz e salinização provocada pelo avanço do oceano no continente, que foram denunciados por ONGs, como o GREENPEACE, e Torres et al. (2018), da conjunção desses impactos com a criação bubalina na foz do rio Araguari.

moradores bloquearem a passagem de carros, ônibus e caminhões, criticando a falta de energia, que para eles ainda é oferecida pela geração termelétrica a óleo diesel, fornecido pelo Governo do Estado, e que em diversos momentos é interrompido por escassez de combustível. As linhas de transmissão passam pela região para atingir a Usina Hidrelétrica de Santo Antônio, e em nenhum momento são cumpridos os acordos de transformação de parte da energia para o atendimento local. 
Mapa 3- Amapá: conflitos por barragens

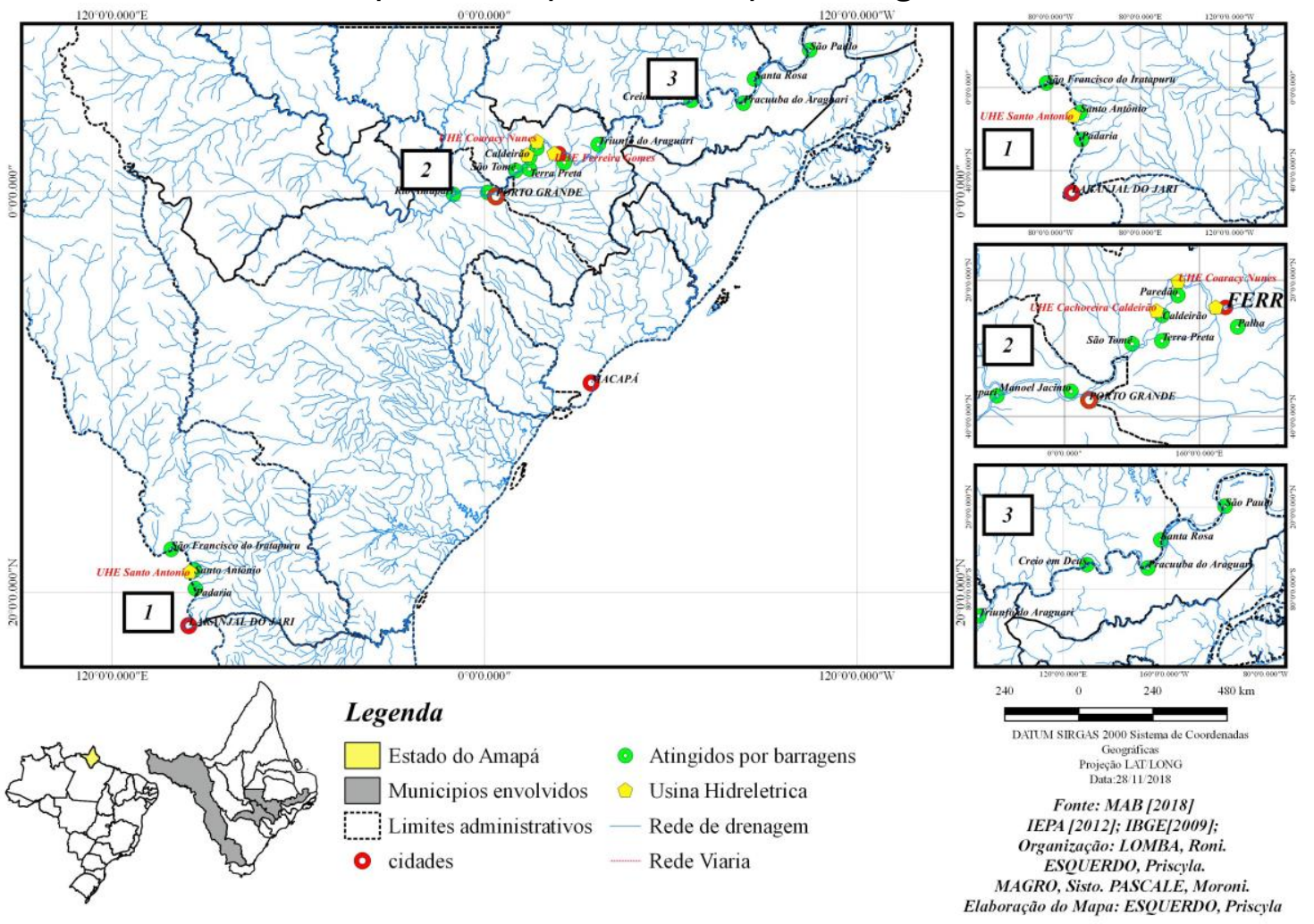

Fonte: MAB (2018) IEPA (2012); IBGE (2009). Organização: Roni Mayer Lomba, Priscyla Esquerdo, Sisto Magro, Moroni Pascale. Elaboração do Mapa: Priscila Esquerdo.

Como se observa no Mapa 3, foram três recentes novos empreendimentos hidrelétricos, afetando diretamente quinze comunidades, sendo que em 2018 haviam registrado quinhentas e vinte famílias envolvidas em conflitos pela água (CPT, 2018). Em campo acompanhamos as consequências após a instalação das hidrelétricas. Relatou-se as diversas promessas não cumpridas, especialmente em termos de indenização, fatores que transformaram a vida dos ribeirinhos para uma situação de mais pobreza, com redução ou inviabilização dos seus meios de vida originais. Segundo relatos em campo a respeito,

Agricultores e pescadores continuam se virando. Só que para eles ficou mais difícil, e os que foram indenizados gastaram o dinheiro comprando casa em outros bairros mais distantes. E por isso que nesse terreno não havia nada, apenas uma armação de madeira, que ainda tem as telhas, e a nossa indenização da casa foi $R \$ 102.000$ mil reais. E com $R \$ 80.000$ mil reais em Macapá ou Santana eu compro uma casa boa. Porque as casas que existiam aqui foram para leilão, eu ofereci $\mathrm{R} \$ 60.000$ mil nesse terreno e quando fui buscar a pasta com documentos, já havia uma nova oferta no valor de $\mathrm{R} \$ 80.000$ mil reais, eu cobri a oferta. Porque o que iria adiantar, comprar uma casa de $\mathrm{R} \$ 30.000$ mil reais e ficar muito distante, e não conseguir trabalhar. Aqui é o nosso serviço, nosso terreno, nossa morada, deixa na embarcação e vem trabalhar. $O$ dinheiro que restou da indenização foi $R \$ 22.000$ compramos o gerador e guardando dinheiro até o máximo. Só onde eles chegaram com a indenização até o senhor Francenildo, um terreno que pertencia a dona Valéria e era limite com o nosso, reuniram a documentação mas não a indenizaram, para você ver a covardia. A casa de forno dela todo ano vai para o fundo. Ela entrou na justiça. Então do terreno do senhor Francenildo para baixo, que estão em 
área de assentamento que havia alguma benfeitoria no terreno, eles deram auxilio moradia, e a empresa fez alguma negociação com o INCRA.

Decorrente à criação das novas hidrelétricas no estado foram registrados conflitos envolvendo mortalidade criminosa de peixes no Rio Araguari, redução ou inviabilização dos meios de vida ribeirinhos, inundação na cidade de Ferreira Gomes e danos materiais provocados pela empresa que resultou na criação do $M A B$ em 2016. Em campo foram acompanhados diversos casos de famílias que passaram por situação de vulnerabilidade social ou que modificaram substancialmente suas formas de trabalho. Abaixo apresentamos algumas imagens locais.

Figura 2 - Amapá: conflitos pela água
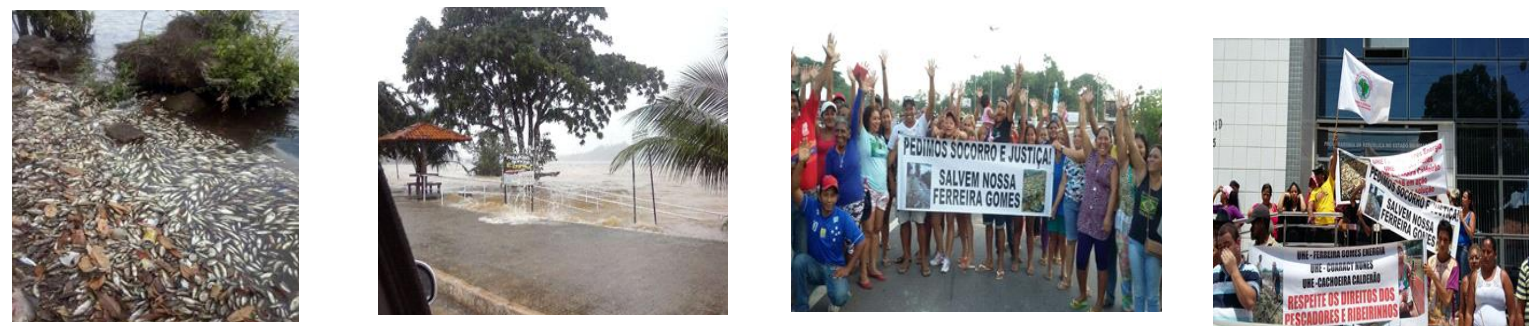

Fonte: Guimarães e Batista (2018).

\section{Desmantamento e outros conflitos ambientais}

O Amapá, decorrente dos fatores históricos de ocupação e as novas legislações mais rígidas no contexto da preservação, manteve seu território relativamente conservado, transformando, nas últimas décadas, boa parte em áreas protegidas. Atualmente, o avanço da fronteira econômica faz desses espaços alvos de cobiça e interesse pela exploração vegetal, mineral ou ambos. Em resposta a dois questionamentos, uma entrevistada, representante do FACADE, assim relatou: sobre a expansão da agricultura em áreas já antropizadas é exclusivamente sobre o cerrado? E se as áreas protegidas já regulamentadas têm garantido a não proliferação dos desmatamentos?

Isso é uma grande falácia, e o discurso usado pelo Governo e o setor produtivo. As provas contrárias são as multas aplicadas pelo IBAMA pelo uso de correntão para desmatamento. Temos fotos de piras enormes de vegetação de cerrado sendo queimadas, a fumaça podendo ser vista a mais de $100 \mathrm{~km}$ de distância, inclusive, vale uma conversa com o GREENPEACE, pois eles, além de imagens, estão questionando o pacto dos produtores de soja (que acho que a APROSOJA faz parte) de não desmatamento de novas áreas no bioma Amazônia, desta forma não estariam fora do pacto assumido. Mas eles não contabilizam como Amazônia por ser cerrado.

Sobre a segunda indagação:

Isso também é uma falácia e já temos casos de soja plantada dentro de área de floresta, ou transição savana-floresta dentro de área de unidade de conservação. Houve denúncia ao MPE e ao Governo do Estado, mas nada foi feito, pois os sojeiros usam títulos de posse emitidos pelo Terra Legal. Iniciativa esta que está sendo investigada pelo MPE e justiça. A área da Floresta Estadual do Amapá hoje é a nova fronteira de especulação de terra. $1 / 3$ da UC está grilada, cerca de 1 
milhão de hectares! MPE assinou ano passado TAC com o Governo do Estado determinando a suspensão dos cadastros, das licenças, etc.

A Secretaria de Estado de Meio Ambiente (SEMA) publicou, em 2017, o mapa sobre focos de desmatamento (Mapa 4). Nele observamos registros nas margens das rodovias BR-156 e AP-70, nas áreas de expansão de agricultura, mas também em áreas protegidas, como unidades de conservação, assentamentos e terras indígenas. Somam-se também aquelas terras em que foram autorizados estudos para prospecção mineral, grande parte sobre áreas de preservação, como o caso da Floresta Estadual do Amapá (FLOTA) e assentamentos da reforma agrária. segundo relato de entrevista:

\begin{abstract}
a FLOTA ela não foi arrecadada. A FLOTA está praticamente toda em domínio da União, até hoje tá dentro das glebas da união; o que eu entendo é que nessa negociação do governo do Estado com o governo federal, porque lá no primeiro decreto que o Lula, assim para garantir a transferência de terras da união, ele condiciona a transferência, a criação de uma floresta de produção que especialmente protegida, mas de produção. Agora, então, a FLOTA ela é criada pelo governo do estado, na época do Waldez em 2006, né? dentro de um acordo com o governo federal para transferência de suas terras, Waldez cria a partir de 2011, de direito mas não de fato, então você tem um território imenso, toca pau nesse território. A gente finge que não vê, não tem fiscalização, não tem plano de manejo, não tem nada tecnicamente. Mas cumprimos o que tá lá no decreto, a floresta tá criada. Mas na prática, apropriação privada é do recurso público madeireiro dentro tirando madeira, mineração correndo solta enfim, o Incra expandindo as áreas de assentamento para cima da área da FLOTA, sem decreto sem processo regulatório sem nada, ninguém contesta absolutamente nada, então assim ela é uma unidade de conservação de papel.
\end{abstract}

O fato de haver reconhecido e registrado tais áreas, portanto, proibido atividades de grande impacto, oficialmente não tem impedido o uso intensivo das áreas protegidas para fins econômicos, como o caso da FLOTA, que tem se tornado área prioritária de desmatamento, uma área de conservação que permite apenas aquelas de baixo impacto ambiental, e está constantemente sendo reportada como lugar do avanço do desmatamento e da expansão da agricultura e madeireira. Outro fato relevante são as áreas de estudos e prospecção mineral, que também sobrepõem área considerável, especialmente em terras de preservação

Mapa 4 - Amapá: focos de desmatamento 


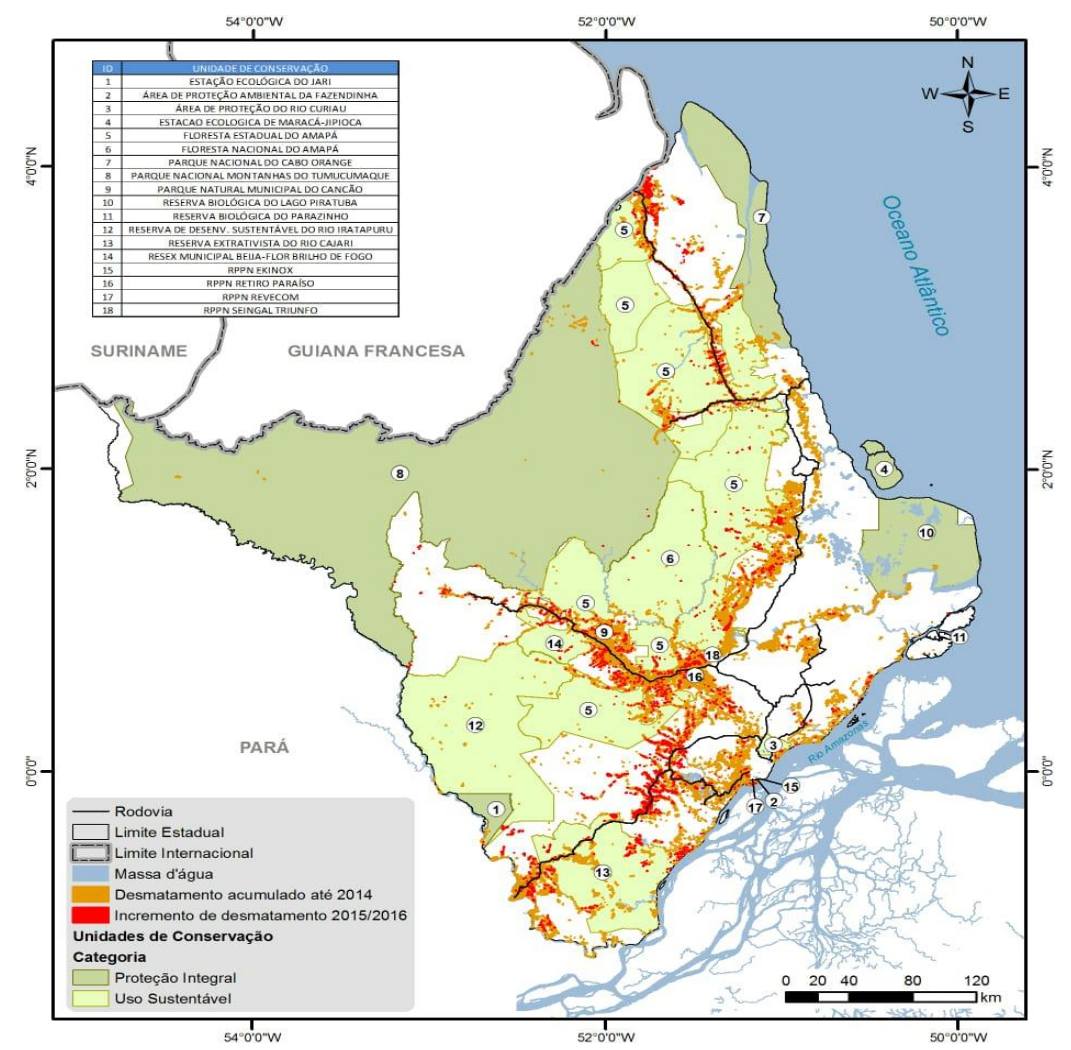

Mapa 5 - Amapá: áreas de estudo de prospecção mineral
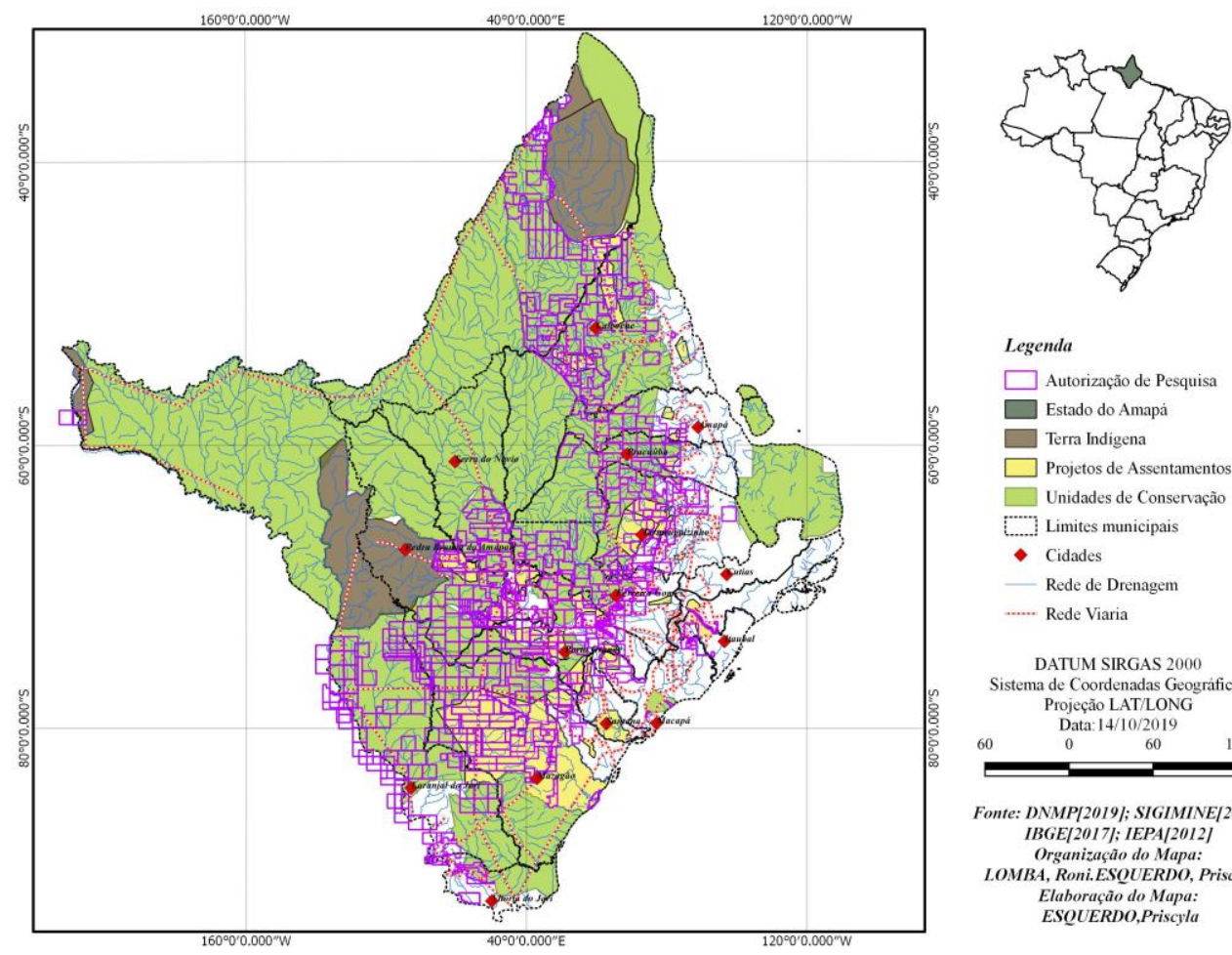

Legenda

$\square$ Autorização de Pesquisa

$\square$ Estado do Amapà

$\square$ Terra Indigena

$\square$ Projetos de Assentamentos

$\square$ Unidades de Conservação

Limites municipais

- Cidades

- Rede de Drenagem

-..... Rede Viaria

DATUM SIRGAS 2000 Sistema de Coordenadas Geográficas Projeção LAT/LONG

Data: 14/10/2019

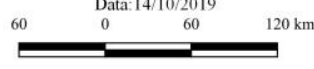

Fonte: DNMP[2019]; SIGIMINE[2019] IBGE[2017]; IEPA[2012]

Organização do Mapa:
LOMBA, Roni.ESQUERDO, Priscyla Elaboração do Mapa:
ESOUERDO,Priscyla 
Fonte: DNMP (2019); SIGIMINE (2019); IBGE (2017); IEPA (2012). Organização do Mapa: Roni Mayer Lomba, Priscila Esquerdo. Elaboração do Mapa: Priscyla Esquerdo.

Assim, as áreas do Amapá cobiçadas pelos interesses privados (relacionados a agropecuária, mineração e madeireira), estão diretamente ligadas àquelas em vias de serem regularizadas para uso privado, áreas de preservação, como o caso da FLOTA, e outras, que com mais de 2.300 .000 ha têm sido alvo dessas atividades destacadas, além dos assentamentos, que, maliciosamente criados em áreas de difícil acesso e sem viabilidade econômica, têm se transformado em áreas de exploração madeireira a partir da concessão do lote pelo beneficiado para manejo florestal (LOMBA; SILVA, 2014). O trabalho de Batista (2018) apontou a transformação de floresta em pastagem, em estudo de um assentamento, verificando em outros casos o abandono da terra.

Consideramos que a retomada do projeto desenvolvimentista, especialmente nas últimas décadas, tem sido suficiente para promoção do tensionamento social e degradação ambiental, envolvendo interesses de grandes capitalistas pela terra, seus recursos florestais e madeireiros. Em diversos setores, como os assentamentos da reforma agrária, que em muitas situações devem ser analisadas como contrarreforma agrária (OLIVEIRA, 2007), serve mais para inflar números e atender a outros interesses que necessariamente promover justiça social no campo. Os mapas 4 e 5 apontam a dimensão da expansão do desmatamento e possibilidades de novas áreas de mineração, que, corroborada com o projeto neoliberal vigente no Estado, há grandes possibilidades de obterem êxito.

\section{Considerações Finais}

Concluindo essa investigação, ressaltamos os seguintes aspectos:

Em primeiro, a fronteira econômica, no caso da Amazônia amapaense tem se tornado espaço privilegiado para expansão de novos/velhos negócios capitalistas. A evolução da agricultura reproduz as mesmas características históricas que permearam a ocupação da Mata Atlântica, os cerrados e, desde os anos 1970, a Floresta Amazônica, sendo que o Amapá se coloca enquanto território de avanço. A lógica permanece a mesma: apropriação de recursos baratos, como terra, trabalho e outros para produção de gêneros que atendem o interesse de mercados nacionais e estrangeiros. A mesma condição se aplica aos empreendimentos minerais e energéticos que pouco ou nada contribuem para desenvolvimento local, mas geram degradações sociais e ambientais.

Segundo, a sociedade local, dominada ideologicamente pelo discurso do desenvolvimento é fatalmente atingida, seja pela expulsão da terra/território, seja pela reprodução da riqueza que não é revertida em benefícios sociais.

Consideramos que as transformações socioeconômicas em tese deve, ou deveria, contemplar melhorias das condições de vida daqueles que vivem no lugar, um direito constitucional que determina que a terra pública seja destinada à reforma agrária, não ao agronegócio, por exemplo. Porém, em diversos momentos, o que se observa é o intenso desejo político de gerar desenvolvimento econômico através das práticas tradicionais, que, tanto desterritorializa, gera conflitos, ao passo que impede o desenvolvimento de novas atividades mais sustentáveis que já 
são aplicadas, inclusive, como o desenvolvimento do extrativismo florestal, empreendedorismo local, turismo entre outros.

\section{REFERÊNCIAS}

AGENDA 21 BRASILEIRA. Brasília: MMA, s/a. Disponível em: <http://livroaberto.ibict.br/bitstream/1/963/1/Agenda\%2021\%3A\%20avalia\%C3\%A7\%C3\% A30\%20e\%2oresultados.pdf >. Acesso em: 08 nov. 2019.

BATISTA, E. M. Da floresta à pastagem: mudanças na paisagem de um assentamento rural na Amazônia Brasileira. 2018. Tese (doutorado em Geografia). Universidade Federal de Santa Catarina, 2018.

BNDES. Base de contratações BNDES transparente. Base de dados obtida via sistema Acesso a informação. 2019. Disponível em: <https://www.bndes.gov.br/wps/portal/site/home/acesso-a-informacao/acessoinformacao-licitacoes-contratos>. Acesso em: 15 jan. 2020.

COMISSÃO PASTORAL DA TERRA. Conflitos no campo Brasil. Centro de Documentações Dom Tomás Balduíno. São Paulo: Expressão Popular, 2013 a 2018.

FELICIANO, C. A. Território em disputa: Terras (re)tomadas. (Estado, propriedade da terra e luta de classes no Pontal do Paranapanema). 2009. Tese (Doutorado em Geografia). Universidade de São Paulo, 2009.

FERNANDES, B. M. Movimentos socioterritoriais e movimentos socioespaciais: contribuição teórica para uma leitura geográfica dos movimentos sociais. Revista Nera: Presidente Prudente Ano 8, n. 6 p. 14 - 34 Jan./jun. 2005

FERNANDES, M. S; DINIZ FILHO, L. L. Planejamento territorial da IIRSA: conceitos e projetos. Revista de Geopolítica, v. 8, nº 1, p. 01 - 18, jan./jun. 2017.

GALLAZZI, Sandro. Ilegalidades nas terras do Amapá. In: LOMBA, R. M.; RANGEL, K. S.; SILVA, M. G.; SILVA, G. G. (Orgs). Conflito, territorialidade e desenvolvimento: algumas reflexões sobre o campo amapaense (Vol. 2). 1 ed. Macapá: EDUNIFAP, 2016, v. 1, p. 194-213.

GUIMARÃES, M. P. B; BATISTA, N. C. F; O grandes empreendimentos energéticos e a disputa pela água: o caso do Rio Araguari. In: LOMBA, R. M.; SILVA, E. C.; SILVA, G. G. (Orgs). Conflito, territorialidade e desenvolvimento: algumas reflexões sobre o campo amapaense (Vol. 3). 1 ed. Macapá: EDUNIFAP, 2018, v. 1, p. 143-160.

IBGE. Instituto Brasileiro de Geografia e Estatística. Censo 2010. Disponível em: <http://www.censo2010.ibge.gov.br>. Acesso em: maio 2015. 
Amapá, População. Disponível em: <https://cidades.ibge.gov.br/brasil/ap/ panorama>. Acesso em: 16 out. 2019.

LOMBA, R. M.; SILVA, I. C. O crédito rural na agricultura familiar no estado do Amapá. Informe Gepec, UNIOESTE, Campus Toledo, Cascavel - PR, v. 18, n. 2, p. 2036. 2014. Disponível em: <http://e-revista.unioeste.br/index.php/gepec/ article/view/10478>. Acessado em: maio 2015.

MARTINS, J. S. Fronteira: a degradação do Outro nos confins do Humano. São Paulo, Contexto: 2009.

MARX, K. O Capital: crítica da economia política - Karl Marx; apresentação de Jacob Gorender; coordenação e revisão de Paul Singer; tradução de Regis Barbosa e Flávio R. Kothe. São Paulo: Nova Cultural, 1988.

MOORE, J. W. The Capitalocene, Part I: on the nature and origins of our ecological crisis, The Journal of Peasant Studies, 2017. Disponível em:

<http://dx.doi.org/10.1080/03066150.2016.1235036>. Acesso em: maio 2018.

OLIVEIRA, A. U. Modo de produção capitalista, agricultura e reforma agrária. São Paulo: Labur Edições, 2007.

RÜCKERT, A. A.; CARNEIRO, C. P. América do Sul: infraestruturas em regiões periféricas e tendências atuais. Rev. Bras. Est. Def., v. 5, nº 1, jan./jun. 2018, p. 329361.

SANTIAGO, A. Amapá tem 380 mil hectares com indícios de grilagem de terras, diz CPT. Portal G1 Amapá, 16 de julho de 2013. Disponível em:

<http://g1.globo.com/ap/amapa/noticia/2013/07/amapa-tem-380-mil-hectares-comindicios-de-grilagem-de-terras-diz-cpt.html>. Acesso em: 09 mar. 2019.

SILVA, E. C. A Lei 13.465/17 e seus impactos sobre a regularização fundiária na Amazônia Legal e no Amapá. In: LOMBA, R. M.; SILVA, E. C.; SILVA, G. G. (Orgs). Conflito, territorialidade e desenvolvimento: algumas reflexões sobre o campo amapaense (Vol. 3). 1 ed. Macapá: EDUNIFAP, 2018, v. 1, p. 143-160.

SILVA, I. C. Da ação social da Comissão Pastoral da Terra no Estado do Amapá. 2018. Trabalho de Conclusão de Curso. (Graduação em Geografia) - Universidade Federal do Amapá.

SMITH, R. Propriedade da terra e transição. São Paulo: Ed. Brasiliense, 1990.

TRECCANI, G. D. O Título de Posse e a Legitimação de Posse como formas de aquisição da propriedade. Revista da Procuradoria Geral do Estado do Pará, v. 20, p. 121-158, 2009. 
TORRES, A. M.; EL-ROBRINI, M. ; COSTA, W. J. P. . Panorama da Erosão Costeira no Brasil: Amapá. In: MUEHE, Dieter (Org.). Panorama da Erosão Costeira no Brasil. 1 ed. Brasília: Ministério do Meio Ambiente (MMA), 2018, v. , p. 19-63.

Roni Mayer Lomba. Pós-doutor em Ciências Sociais pela Universidad Nacional de la Patagonia Austral; Doutor em Geografia Humana pela Universidade de São Paulo. Professor Associado da Universidade Federal do Amapá. Rua Amadeu Gama, 2143, lote 09, Universidade, Macapá-AP.ronimayer@hotmail.com

Alejandro Fabian Schweitzer. Doutor em Geografia. Pós-doutor em Desenvolvimento Regional. Consejo Nacional de Investigaciones Científicas y Técnicas: Rio Gallegos, Santa Cruz, AR. Av. Gregores y Piloto "Lero" Rivera, Z9400 Río Gallegos, Santa Cruz, Argentina. Alejandro.schweitzer@gmail.com

Jadson Luís Rebelo Porto. Geógrafo. Doutor em Ciência Econômica. Pósdoutorando em Desenvolvimento Regional no Programa de Pós-graduação em Desenvolvimento Regional (PPGDR/UFT). Professor titular da Unviersidade Federal do Amapá. Rodovia JK, KM02, Jd. Marco Zero do Equador, Macapa, Amapá. Jadsonporto1967@gmail.com

Como Citar: LOMBA, Roni Mayer; SCHWEITZER, Alejandro Fabian; PORTO, Jadson Luís Rebelo. Ordenamento territorial e conflitos por terra no Amapá - Amazônia - Brasil. Redes (St. Cruz Sul, Online), Santa Cruz do Sul, v. 25, p. 1553-1575, nov. 2020. ISSN 1982-6745. doi:https://doi.org/10.17058/redes.v25i4.15214.

\section{CONTRIBUIÇÃO DE CADA AUTOR}

a. Fundamentação teórico-conceitual e problematização: Roni Mayer Lomba

b. Pesquisa de dados e análise estatística:Roni Mayer Lomba; Jadson Luis Rebelo Porto

c. Elaboração de figuras e tabelas: Roni Mayer Lomba

d. Fotos: Roni Mayer Lomba

e. Elaboração e redação do texto: Roni Mayer Lomba, Jadson Luis Rebelo Porto; Alejandro Fabian Schweitzer

f. Seleção das referências bibliográficas: Roni Mayer Lomba, Jadson Luis Rebelo Porto; Alejandro Fabian Schweitzer

Fontes de financiamento: Consejo Nacional de Investigaciones Científicas y Técnicas (CONICET) - concessão de bolsa para pós doutorado para alunos latinoamericanos. 
Ordenamento territorial e conflitos por terra no Amapá - Amazônia - Brasil

(c) (†) 